\title{
私の推奨する麻酔法 : 開腹手術の麻酔
}

\section{$\mathrm{mNLA}$ 法}

\section{脇田勝敏*}

1959 年, DeCastro と Mundeleer が neuroleptics と analgesics を用いて NLA- I 法を始めて以 来, NLA はドロペリドールとフェンタニルによる NLA-II法，笑気を併用して意識を取り，Neurolept-anesthesia（NLA 原法)，さらにさまざまに修 飾されベンゾジアゼピンと拮抗性鎮痛薬の組み合わ せも含め mNLA と総称されてきた。

しかし，われわれは Shephard が定義したように neuroleptには, (1)自発運動の消失とカタレプシー 症状，(2)アンフェタミンによる中枢興奮に拮抗，(3) カテコラミンの感受性を抑制, (4)アポモルフィンに よる催吐作用に拮抗，の 4 点が必要であることか ら, mNLAであっても neurolepticsとして butirophenones が必須であり，そのうちでもハロペリ ドールは作用時間が長く, 錐体外路症状が強く麻酔 には不適切であるため, ドロペリドールが不可欠で あると考えている.

また analgesics としては, (1)麻薬のように使用 が繁雑でない, (2)呼吸, 循環抑制が比較的少ない, (3)作用時間が短く調節性に富む，などの理由からぺ ンタゾシンを用いている。

NLA 麻酔の長所はまず，(1)揮発性麻酔薬の欠点 であったカテコラミンの心筋感受性増加, 体内代謝 に伴う臓器障害, 悪性高熱症の誘発がない, (2)吸入 麻酔単独に比し, 術後の鎮静, 鎮痛効果に優れてい る, (3)麻酔深度が浅い点を利用し, 低血圧や低栄養 の比較的ハイリスク患者にも応用できる，などであ

*近畿大学医学部麻醉科学教室
ろう。また, 久点は(1)麻酔深度の調節性に欠ける, (2)術中覚醒の可能性がある, (3)フェンタニルの作用 として, 鉛管現象, 呼吸抑制, 喘息誘発, (4)ドロペ リドールの作用として, 錐体外路症状, (5)薬剤代謝 に関わるほどの重症肝障害患者には使えない，6胎 盤移行性の点で産科麻酔には不適切, などがあげら れる。われわれはこれらの長所を活かし，欠点を削 減する意図でフェンタニルに替えて, ペンタゾシン を使用した。さらに, 術中覚醒に備えミダゾラムを 加味し, 静脈麻酔薬の全量を抑え低濃度のセボフル ランを使用することで調節性を高めた。これらの薬 剤が理論的に相乗作用を現わすなら，最少有効血中 濃度で麻酔に必須な 4 条件（意識抑制, 知覚遮断, 運動遮断，反射抑制）を満たす理想的な MNLA が できると考えた。

以下，当施設で理想的と考える mNLA 法につい て述べる. 前投薬は入室 30 分前に経ロクロニジン $150 \mu \mathrm{g}$ とミダゾラム $2 \sim 3 \mathrm{mg}$, アトロピン $0.5 \mathrm{mg}$ 筋注とする. 入室後ドロペリドール 2.5〜 $5.0 \mathrm{mg}$ 静注投与 1 分後に, ミダゾラム $4 \mathrm{mg}$ とベクロニウ ム $4 \mathrm{mg}$ の混合投与と同時に GO で補助呼吸を開始 する.さらに 1 分後, チアミラール $100 \mathrm{mg}$ を投与 して, その 1 分後に気管内挿管を行なう. 執刀約 15 分前にペンタゾシン $60 \mathrm{mg}$ iv. 術中麻酔維持に は GO にペンタゾシン $15 \mathrm{mg}$ を適宜追加投与して 行なう。血圧上昇に対しては低濃度セボフルランか ニカルジピンなどの血管拡張剤で対処する，侵襲の 少ない短時間手術ではこれのみで適度な術後鎮静, 鎮痛が得られるが, 開腹術の場合, PCA ポンプに 
よるペンタゾシンの静脈内投与が必要である。われ われはバクスター・インフューザーにペンタジンTM $7 \mathrm{~A}$ とドロレプタンTM $3 \mathrm{~m} l$ （計 $10 \mathrm{ml}$ ）を注入し, PCA 1 回につきペンタゾシン $10 \mathrm{mg}+$ ドロペリ ドール $0.375 \mathrm{mg}$ が静注されるようにセットして術 後使用した。バクスター・インフューザー24時間 タイプTMにバクスターPCM ${ }^{\mathrm{TM}}$ 接続すると, cut -off time が 15 分になり, 投与間隔が適度で安価な 簡易 PCA ポンプになる。

\section{II 血行動態}

上腹部手術にこの麻酔法で望んだ上腹部手術群 $(\mathrm{n}=21)$, 同様にこの麻酔法による下腹部手術群 $(\mathrm{n}=13)$, さらに当施設で前投薬にクロニジンを投 与していない NLA あるいは mNLA 麻酔で開腹術 を行なったクロニジン（一）群（n=20）の 3 群に 分類して, 血行動態を調べた. 入室時の平均動脈圧 $(\mathrm{mBP})$ ，心拍数 (HR) を $100 \%$ としたときの変化 率で表わすと, 挿管時に上腹部手術群で $\mathrm{mBP}$ が

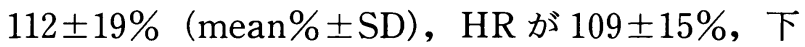
腹部手術群で $\mathrm{mBP}$ が $108 \pm 13 \%, H R$ が $110 \pm 15$ \%,クロニジン (一) 群で $\mathrm{mBP}$ が $119 \pm 21 \%$, HR が $113 \pm 18 \%$ と 3 群ともに上昇, また抜管時に も同様に上昇しているほかはほほ安定した血行動態 で経過し，全経過を通じ有意な変化を示さなかっ た。この麻酔法により術中の血行動態の安定のみな らず，挿管，抜管時の安定もめざしたが，完全には 得られなかった。群間比較でも有意差はなかった が, mBPではクロニジン (一) 群で高值を示す傾 向にあった。このことから，今回の麻酔法では，前 投薬に投与された経口クロニジンが術中の血圧安定 に寄与した可能性があると思われた。また，HRで は同様に群間に有意差はないが, 下腹部手術群で低 值を示す傾向にあり, 侵襲の比較的少ない下腹部手 術ではクロニジンの影響が前面に出たものと考えら れる. なお, 有意差判定は paired, unpaired student $\mathrm{t}$-test により行なった。

\section{III 術後の覚醒}

麻酔法の選択の基準には術後の速やかな覚醒も重 要である. 回復室での血液ガス分析では上腹部手術 群で $\mathrm{PaO}_{2} 125 \pm 18 \mathrm{mmHg}, \mathrm{PaCO}_{2} 41 \pm 4 \mathrm{mmHg}$, 下腹部手術群で $\mathrm{PaO}_{2} 157 \pm 21 \mathrm{mmHg}, \mathrm{PaCO}_{2} 39 \pm 5$ $\mathrm{mmHg}$ と正常で麻酔覚醒のよいことを示している。 フルマゼニル，ドキサプラムなどの麻酔拮抗薬を投 与した症例は上腹部手術群で 21 例中 4 例, 下腹部 手術群で 13 例中 1 例, 手術終了から抜管までが 30 分以上要した症例は上腹部手術群で 21 例中 2 例, 下腹部手術群で 13 例中 0 例であった. 上腹部手術 群では下腹部手術群に比し侵襲が大きくペンタゾシ ンやセボフルランをより多く使用したため, 若干覚 醒の遅れた症例が認められたが, 術後合併症はな く, 覚醒に関しても問題ないと思われた。

\section{IV 術後鎮静, 鎮痛}

mNLA に引き続きPCA ポンプによる術後鎮静, 鎮痛を調べるため, 上腹部手術群 $(n=18)$, 下腹 部手術群 $(n=12)$ に分けて, 鎮静度 (1 点; 完全 覚醒, 2 点; 呼べば容易に覚醒, 3 点; 体を刺激し て覚醒, 4 点; 不穏, 混乱, 5 点; 昏迷), 疼痛度 ( 1 点; 著効, 疼痛なし, 2 点; 有効, 安静臥床で 痛みなし, 咳, 体動で軽度の痛み, 3 点; やや有 効, 安静臥床にて痛みがある, 4 点; 無効, 耐えら れない痛みがあり, 疼痛のため安静状態が保てな い）を回復室, 術当日夕, 術当日夜, 術翌日朝, 術 翌日夕，術翌々日朝に記録した。また，患者の不利 益にならぬようにあらかじめ, 硬膜外カテーテルを 挿入し, 疼痛度 3 点以上, 鎮静度 4 点以上のとき は, 無効例として, PCA ポンプを中止し, 硬膜外 注入による鎮痛に変更した. 鎮静度は上腹部手術群 で回復室 $1.75 \pm 0.58$ (mean $\pm \mathrm{SD}$ ), 術当日夕 1.88 \pm 0.5 , 術当日夜 $1.73 \pm 0.46$, 同様に下腹部手術群 でそれぞれ $2.20 \pm 0.23,1.90 \pm 0.42 ， 1.33 \pm 0.46$ と両群とも術直後から術当日にかけて適度な鎮静を 示し, 術翌日以後には上腹部手術群, 下腹部手術群 
ともで術翌日朝〜術翌々日朝までほほ $1.00 \pm 0.00$ とよく覚醒していた。術翌々日まで PCA ポンプを 使用した症例では両群とも全経過を通じ疼痛度が 1.00 から 1.50 で経過した。

以上より, 術当日は適度な鎮静がかかり, 術翌日 には完全覚醒していても, 疼痛度は術当日と変わら ずほほ良好な術後鎮痛を得ていたことが示され， mNLA+iv PCAにより良好な術後管理ができると 思われる。しかし, 鎮痛度 3 点以上が持続するため 無効例として PCA を中止した例が下腹部手術群に はみられなかったが，上腹部手術群では $3 / 18$ 例に みられ，上腹部手術に限り，完全な術後鎮痛が得ら れたとはいえない.

バランス麻酔が無計画な garbaged anesthesia と 異なる点は使用される麻酔薬が理論的に相乗効果を 示し，それぞれの使用量を減じて，その副作用を抑 制するところにある.クロニジン，ミダゾラム，ペ ンタゾシン, バルビツレートなどには, 相乗作用を 示す報告があり，それぞれの副作用を抑制しうると
思われる.今回の麻酔法でも比較的少量の神経遮断 薬と鎮痛薬で麻酔維持できたのは, 前投薬のクロニ ジンに依存しているかもしれない。また，クロニジ ン量もやや少量でしかも経口投与で可能なら，クロ ニジンの副作用の抑制や QOL の面からも好都合で ある。

\section{V 結 語}

ペンタゾシンおよびドロペリドールによる mNLA を中心としたバランス麻酔法により，低血 圧を伴わない比較的安定した血行動態，スムーズな 麻酔覚醒, 適度な術後鎮静, 鎮痛が得られたが, 上 腹部手術では術後鎮痛に若干の問題が残った。

\author{
著者連絡先 脇田勝敏 \\ 干 589 大阪狭山市大野東 $377-2$ \\ 近畿大学医学部麻酔科学教室
}

